\title{
Misadventures of an Irresponsible Investor
}

\author{
Jack Gray
}

Jack Gray is at the Paul Woolley Centre for Capital

Market Dysfunctionality, University of Technology, Sydney; Brookvine Pty Limited; and Rawson East PIL, Sydney (Australia).
The ESG movement is nudging toward an unhealthy state of political correctness, one that brooks no criticism (and there is much, but mostly sotto voce). Boards spend excessive time on ESG relative to any expected benefits for the principals; managers cynically sign up to UNPRI else their business suffers; while principals, when given a choice, eschew the option. Nonetheless, ESG raises important questions about the very purpose of fiduciary investing, especially whether a pension fund has any social responsibility beyond generating the greatest risk-adjusted return for its beneficiaries. Jane Ambachtsheer, Stephen Davis, and Keith Johnston were invited to respond to Gray's views. Their comments follow immediately after this article.

Keywords:ESG, Pension Fund, Social responsibility, Sole Purpose Test, Sustainability

\section{Irritations}

I was once arguing heatedly that boards of superannuation / pension funds spend excessive time on environmental, social, and governance (ESG) factors relative to their potential to improve members' benefits when my rant was interrupted by a trustee gently asking why I was so irritated (and irritating). ${ }^{1}$ After some soul-searching, I have a few answers.

Some investors are irritated by the ever-changing names and nature of the topic. To them the plethora of acronyms SRI (socially responsible investing), CSR (corporate social responsibility), PRI (principles of responsible investing), ESG, EI (ethical investing), ETI (economically targeted investing), II (impact investing) ... - indicates a search for a catchy title. I side with the less cynical, who see it more as a healthy search for fundamental issues and modus operandi. The current version seems to be that "investors should better account for the often longer-term impact of environmental, social and governance factors on the future cash flows of their investments." Analysts and portfolio managers claim they have always accounted for such non-financial factors, the CEO's health and the likelihood of regulation being oft-cited instances. Investors in longduration assets such as infrastructure have long recognized and been highly sensitive to all three of the letters $E$, $S$, and $G$. Nonetheless, the movement may have driven analysts and portfolio managers to go beyond the cosmetic to attach a modicum of substance to non-analytic factors.
In principle, because the above definition eschews moral and ethical considerations unless they affect cash flows and valuations, it resides comfortably within the normal paradigm of economic rationalism. In practice, purely moral and ethical considerations continue to underlie much ESG discussion and decision making, regardless of their effect on cash flows. The current British Under-Secretary of the Department of Works and Pensions supports that practice, seeing "no reason why trustees [of pension funds] cannot consider moral and social criteria in addition to their usual [financial] criteria" (qtd. in Johnson and de Graaf 2009, 6) - considerations that can readily run counter to fiduciaries' responsibility to act solely in the best interests of beneficiaries. ${ }^{2}$

But even that narrow definition of ESG irritates, because boards $d o$ spend too much time on it relative to its potential to improve members' returns. One of the initiators of the United Nations Principles for Responsible Investing (UNPRI) pointedly suggested that because ESG doesn't detract from returns (a far from settled assertion), investors should be as responsible as possible. But this ignores the direct cost of acquiring ESG information and the indirect cost of spending less time on opportunities with greater potential benefits. A hallmark of committees is a predilection for avoiding difficult and uncertain tasks by instead focusing on those that make committee members feel good, or those that solve a problem well chosen for its simplicity and immediacy. ESG offers scope for both avoidance techniques. For example, by spending time favoring and selecting well-governed companies and countries, 
ESG investors risk overpaying for the "privilege" of owning them, almost regardless of price. In emerging markets, a bias toward countries that rank high on ESG factors will lead investors to miss the opportunities expressed in the adage that the greatest returns in emerging markets occur when a country progresses from absolutely rotten to just plain awful, though it may be the better-governed companies that contribute most to greater country returns.

$E$ for engagement is largely a time-wasting feel-good activity, especially for boards of smaller funds dealing with companies with broad and varied shareholders. According to one ESG believer, most of the activity classified as "engagement" is dancing around with corporate management, who are masters at engaged listening inactivity, a core competency they develop from explaining themselves to hordes of analysts and portfolio managers. The investors who can best trigger substantive corporate change are (some) activist hedge funds and (some) operationally focused private equity managers, though even their success rate is limited despite their substantial and sometimes controlling stakes. The ESG movement could learn from them.

\section{Thank You for Smoking}

My irritation flows in diametrically opposite directions, toward cynics and true believers alike. Cynical funds use UNPRI as a marketing ploy, or as a form of "ethical narcissism," or to protect careers. Cynicism reaches its nadir with the CEO who prices his ESG overlay service as a form of career insurance, with fund managers who sign up because they've been told they'll get no business unless they do, and with Citigroup's Vikram Pandit's commitment to "responsible finance," surely the epitome of empty feel-good marketing. As for true believers, many, especially in the United States, are religious about ESG in the most pejorative sense, being possessed of a deep and abiding self-righteousness that sees ESG as the dominant, if not the sole, issue. Theirs is a religion that brooks neither disagreement nor discussion. I once pitched a tobacco-free American equity mandate to a committee of such zealots. Showing an out-of-character sniff of commercial nous, I didn't mention that the tobacco sector of the S\&P500 had been the best performer over the past 30 years, and by a long way. I did, however, plead for the freedom to short selected tobacco stocks, an action that might damage the stock price and help the committee's moral cause. My naïve plea was irrationally and irritatingly dismissed with "We want nothing to do with tobacco."

The first CEO of the Canada Pension Plan Investment Board was once pilloried because CPPIB held tobacco stocks.
Although concurrently serving on an oncology hospital board, he defended CPPIB's holdings: As a fiduciary, he saw his responsibility as generating the highest return possible within acceptable levels of risk; as a citizen, he saw his responsibility as actively campaigning against tobacco. Courageously, he wrote an op-ed piece to that effect in the Globe and Mail (MacNaughton 2004). He was a responsible fiduciary investor and a responsible citizen. In the spirit of the Nobel Prizewinning Dutch economist Jan Tinbergen's "two goals, two instruments," this is as it should be, though the dichotomy will fray at the edges if, for instance, tobacco companies spend their earnings lobbying against government regulations. The "universal owner" idea tries to extricate investors from this predicament by arguing that successful lobbying will result in externalities, such as increased public spending on health and a consequent rise in taxes, that will lower returns on the balance of the portfolio. It seems unimaginable that, over the past 30 years, that effect would have outweighed the returns from tobacco.

More worrying (to me) is how this simple dichotomy leans toward Milton Friedman's view that a firm's only social responsibility is to (legally) generate profits, a view that would uniquely position firms as having no broader responsibilities to society. My total rejection of that position exposes me to a conundrum: Is a pension fund's only social responsibility to (legally) generate returns for members? Not for the first time, I find myself struggling.

\section{Value in Investing in Values?}

Implicitly, and sometimes explicitly, ESG advocates claim that eventually investment factors and society's values will converge, or at least will be highly correlated, so the financial effect of those values should be included as portfolio risk factors. This claim relies on three heroic assumptions.

The first is that they will converge or be correlated, an assumption fraught with sociological, political, and philosophical challenges. Even when a society's values are enshrined in black-letter law, convergence may remain an ideal. For a generation, discrimination against women has been illegal in most developed Western countries, yet companies that discriminate through unwritten hiring policies, lower wages, and glass ceilings continue to thrive and do not appear to be priced at a discount to fair value. That supposed risk factor has not materialized. The globalization of investments makes convergence even less likely, as rarely will values globalize. Values will diverge locally for the same reasons that languages (even artificial computer languages) diverge locally. Inevitably, these local divergences of values will cause friction with global investment factors. 
The second implicit assumption is that society's values are "good," "moral," and "responsible," one that smacks of the debunked Whig historiography, so popular in Victorian England, that history is intrinsically "progressive." The ubiquity of war and the abject refusal of countries to disarm, Costa Rica excepted, is the most glaring of many counterexamples. Shorttermism is a more apposite example. While we can all agree that an excessive focus on the short term is destructive in multifarious ways, short-termism is one of society's current values, and it shows no sign of abating.

Assumption three holds that investors can monetize convergence because eventually society's values, such as the demand for clean air, will be priced in by the market. Maybe so. But monetizing convergence is notoriously difficult, because both its path and its timing are largely unpredictable. The social cost of alcohol and the need to regulate it have been understood at least since the Code of Hammurabi 4,200 years ago. Yet (non-Islamic) societies have done little beyond the margins to hedge alcohol's well-documented damage. Closer to our temporal and cultural home, witness the path and consequences of the United States' failed 13-year experiment to prohibit alcohol consumption. The link between lung cancer and smoking was first broadly publicized with the American Surgeon General's 1964 report (though somewhat earlier Germany's Nazi government had fought an effective public anti-cancer campaign against smoking). Yet a generation and a half later, many Western European countries have taken only minimal action, and sometimes none at all, on this costly public-health issue.

"Eventually," then, is best measured not in years but in generations, a unit so large that investors' default position should be deep skepticism about when and how to hedge convergence risk. Much ESG discussion is strikingly naïve about long-term investing, as if it were synonymous with buy-and-hold (it isn't), clearly defined (it isn't), appropriate for everyone (it isn't), and relatively straightforward to get to (it isn't), and as if, once there, it were a land of milk and honey (it isn't). John Maynard Keynes, the most profound of longterm investors, eloquently warned that "it is not wise to look too far ahead; our powers of prediction are slight, our command over results infinitesimal" (Keynes 1936, ch. 12).

Timing uncertainty induced one CIO to be "long brown / short green" until the signals clarify somewhat, at which point he'll edge to the hedge of "long green / short brown." Given the world's hesitant-to-nonexistent move in the direction of green, a world where coal is resurging and is expected to overtake oil as a fuel by 2025 , is he being irresponsible? As a citizen, he has a responsibility to push the world toward green; as a fiduciary, he has a distinctly different responsibility. The Norwegian Oil Fund has a forceful ESG investment policy yet invests in a company that is logging Indonesian forests. Simultaneously, the Norwegian government buys forests (not in Indonesia) as part of its social contract to defend the global environment. The accusation of hypocrisy is misguided. The fund is acting responsibly in the interests of people qua fund beneficiaries, while the government is acting responsibly in the interests of people qua citizens. The two goals demand two instruments, as uncomfortable and irritating as that is.

\section{Hypertheticals}

In a 2003 interview with a journalist, my irritation expanded into anger as I expounded on Tony Blair's hypocrisy in encouraging torture in Iraq, and promoting a British company selling cattle prods to the Indonesian military, while requiring British pension trustees to formulate an SRI statement, implicitly demanding ethical standards from trustees higher than those of the ambient society. While admitting that, like all ad hominem attacks, mine was irrelevant to the issue, and under no provocation from the journalist, I offered her a hypothetical. (Advice to the young: Never, ever offer a journalist a hypothetical. And mine was a doozy.) The place is Sweden, the time is early 1942, and I'm a trustee of a pension plan. Through a private equity deal, the plan has the opportunity to own $100 \%$ of a domestic company with an exclusive contract to make gas chambers and export them to Germany. Everything suggests that Germany will expand to the Urals and beyond and claim its sought-after Lebensraum once all Jews, Bolsheviks, Asiatics, and other "undesirables" are exterminated, a program expected to take a generation. The incomparable returns expected from this single investment, and its moderate risks, make it a spectacular and unique opportunity, one that cannot be finessed by the realpolitik of finding an alternative investment with very similar characteristics and expectations. What should I do? And what should I do under the even darker scenario in which the company won't survive without my fund's capital? A literal interpretation of the Sole Purpose Test offers no wiggle room, because the members will be materially worse off if I don't invest. My answer was to resign as a fiduciary and, as a citizen, to take action to stop the company from manufacturing its product.

The article and my picture appeared under the headline "Invest in torture; it's the only moral thing to do." And that was only the beginning. After two years of protracted negotiations, the manager I represented had just won a mandate from an SRI fund. My comments found their way to the fund's deeply selfrighteous board, which irrationally threatened to fire their CEO and cancel our mandate. I wrote to the CEO, apologizing not for my views but for causing her grief. I felt obliged to mention that my mother's entire family had been fed into German gas chambers, so the hypothetical was not created lightly. Both of us, and the mandate, survived, but only just. 
The underlying moral issue remains. A few years later, when I was a fund $\mathrm{CIO}$, one of our largest international holdings was Halliburton, which was making massive profits selling services to the American military in Iraq. Members' benefits were enhanced at the cost of bloodshed and mayhem. Should I have "Wall Street Walked," and sold out, or "Wall Street Talked" by engaging with Halliburton executives and encouraging them to switch to growing organic carrots? On the criteria of the British Under-Secretary of Pensions mentioned earlier, I should have walked. Perhaps Sole Purpose does need reframing within a broader discourse, but only with extreme caution to ensure that beneficial owners remain the sharp and primary focus.

\section{Responding to Responsibility}

The use of responsible is yet another source of irritation. Single emotive words like "responsible" and "sustainable" may make for good marketing, but only by doing violence to the complexity of the underlying issues. The moral high ground implicit in the $R$ of UNPRI brands those who disagree as irresponsible. They are not. Like many who believe we no longer have the luxury of muddling through on climate change, I'm increasingly drawn to the nuclear energy option as a relatively quick fix to save the planet, at the admittedly massive risk of waste disposal. Might nuclear be the responsible and sustainable option? How will UNPRI investors respond to Australia's forthcoming policies of selling uranium to India and opening new mines? In principle, they need not respond, provided the "nuclear risk factor" has been appropriately accounted for in their portfolio construction. But even leaving aside the challenge of "appropriate accounting," in practice the emotive pull of the $R$ word will likely drive decisions on moral, not investment, grounds.

Funds themselves are irresponsible in failing to act collectively in their beneficiaries' interests, a failure (intentionally?) reinforced by agency effects and especially by competition. Arthur Leavitt, ex-head of the Securities Exchange Commission, spoke at a client conference a few years after he had been bruised and beaten by corporate America's lobbying machine for trying to have executive options expensed. Standing before us, he asked, “And where were you? Why didn't you support me?" Silence spoke eloquently to our collective guilt. Pension funds and investment managers, some signatories to the UNPRI, all lacked the moral clarity and courage to act in beneficiaries' best interests. And we still do. The SEC continues to be squeezed for resources, while any proposed actions are instantly lobbied against in Congress. Responsible collective leadership remains sadly lacking.

Some tout sustainability as almost the ultimate responsibility. The strength of the word's emotional tug is a function of its highly elastic meaning. Perhaps the cleanest of many definitions is "the ability of assets, markets, firms and economies to adapt to and to thrive in changing environments without damaging other assets, markets or economies." But even under that broad definition, sustainability is neither intrinsically good nor universally desirable. The most sustainable and often the most profitable industries produce goods and services designed to kill and maim. Would that they were unsustainable.

Sustainability is an extremely rare exception for organizations, markets, firms, assets, societies, empires, languages, and - over evolutionary time scales - even for species. Mere survival is challenge enough and may be undesirable in a dynamic and competitive economy, where death and birth are the "natural" order of things and where organizations struggle mightily to maintain energy, enthusiasm, flexibility, commitment, productivity, and growth for more than brief periods. Companies survive in the S\&P500 index for an average of only 15 years. Rare exceptions, such as IBM and General Electric, have continually reinvented themselves over a century, successfully adapting to changing environments while just surviving neardeath experiences. On the other hand, General Motors and (almost) the entire airline industry have survived for a similar period only by being propped up and bailed out. Yet from an investment perspective, GE is not more desirable than GM just because it's sustainable. Desirability depends crucially on the price paid.

\section{Occupying the Leadership Vacuum}

A major cause of my irritation has roots in the dearth of political leadership reflected in democracy's ineluctable decay to plutocratic populism, driven by the agenda of minimal government, low-to-no taxes, market fundamentalism, and extreme individualism. To my irritation/anger, corporations have occupied the leadership vacuum, thus fulfilling Dwight Eisenhower's 60-year-old warning of the incipient dangers of the "military-industrial complex," which, since the deregulation of the 1980s, must be augmented by "financial." I now realize that I have unfairly projected my irritation/anger onto the ESG movement because it, too, is trying to occupy that vacuum.

I resent the policy of everything for sale - highways, museums, schools, even open space. Privatization has, broadly, been wonderful for vampire squids and other Wall Street denizens, a boon for institutional investors and their beneficiaries, but neutral to poor for society as a whole. As citizens, we were irresponsible in allowing governments to privatize excessively, and often poorly. As fiduciaries, we were responsible in providing capital for privatizations. And that is as it should be. Pension fund fiduciaries should not make policy decisions for society. When I worked at a large Australian manager, the Arnott family 
agreed to sell their eponymous biscuit manufacturer to Campbell's Soup. Public anger was directed at us, as Arnott's largest institutional shareholder, through comments such as "You can't sell an Australian icon to the Americans" and "You're irresponsible acting against the national interest." As a citizen, I didn't want us, the fund manager, making decisions about the national interest - that was government's role. As a fiduciary, our decision was simple, because the offer price was well above fair value, even without Campbell's projected growth in Asia. We sold our entire holdings, and the responsible officer withstood bile spewed at him by shock jocks despite having doing the right thing for beneficiaries. Would ESG investors judge our divestment as irresponsible because we did not sufficiently account for $S$ ? SRI investors certainly did. That officer's character was called on again when Alan Bond, characterized by some as one of Australia's corporate thugs, tried to stack a company board with his acolytes. The decision to vote against stacking fell to that same officer, who properly voted against it on the grounds of $G$. Bond's response was to threaten him over the phone and, it is believed, to have his backyard shed firebombed. We under-appreciate the courage that is sometimes needed to do the right and responsible thing.

As an idealist without illusions, I'm sympathetic to those who want to change the world for the better. Given the vacuum of government leadership, perhaps it is up to trustees and other investors to lead, but only if doing so in the best interests of the beneficial owners. Why, then, don't UNPRI funds engage with governments as firmly as they do with private companies? Global pension funds could tell governments that unless they act more decisively on climate change, funds will sell their sovereign bonds on the pure investment grounds that failure to act will be priced in, as might already be happening with some corporate bonds. Unless the government acquiesced, yields would spike, dragging down economic growth. Pension funds could become "NextGen" bond-market vigilantes, but vigilantes dedicated to goodness, virtue, and purity.
Just after Lehman Brothers collapsed, I was at a conference of large global pension funds. The brewing crisis provided a once-in-a-lifetime opportunity for fiduciaries to assert collective power, and I suggested we draft a manifesto to that effect, to occupy Wall Street, at least in writing. I asked for support from two public-sector funds, both signatories of UNPRI, and was met with "We're public-sector funds, so we can't get involved in politics." Is that responsible? The Street had no such compunctions. Investment banks compete viciously, but they act as one when threatened. Goldman Sachs had already tripled their lobbying budget, and Wells Fargo now spends (a declared) US\$50 million a year on lobbying. With remarkable speed, the financial sector has returned to its old ways, and fiduciaries didn't even fight.

\section{End Rant}

The separation of fiduciary and citizens' duties leaves me unsatisfied and self-irritated. Suppose that forestry is a component of the global equity benchmark, and that the logging company mentioned above denudes the entire Sarawak forest. Investors will extract alpha, a positive for beneficiaries, but at the cost of reducing the future index return (beta). Should fiduciaries care ${ }^{3}$ After all, the dynamic nature of an index will always see industries die and new ones born. But should they care as fiduciaries if logging denudes almost all the planet's forests? Does the Sole Purpose Test need to be rethought in the context of such disaster scenarios, as was suggested in obiter dicta in the British Scargill case, and more forcefully in the 1978 New York City Teachers case? ${ }^{4}$

As citizens, we need to challenge and change that most dominant of all paradigms - the eternal and ubiquitous desire for economic growth. Even the British Conservative PM David Cameron has, to screams of abuse, hinted at this by suggesting an index of well-being or happiness to sit alongside GDP. That would encourage a cautious re-assessment of Sole Purpose to tentatively move it away from its narrow concern with direct financial benefits.

Jane Ambachtsheer, Stephen Davis and Keith Johnson were invited to respond to this article. See end of this article for their comments. 


\section{Endnotes}

1. This article is an expanded version of an after-dinner speech to the Responsible Investment Research Forum, Sydney University, November 2011. I especially thank Susheela PeresdaCosta and Danyelle Guyatt for the trenchant criticism that is so essential but so rare. Thanks also to Julian Poulter, Rob Bauer, Ross Barry, Rob Prugue, Gareth Abley, Greg Hickling, and Steve Hall. The views expressed here are personal and not necessarily representative of any organizations with which I am affiliated. Brickbats and bouquets welcome at jackgray08@live.com.au.

2. The head of communications at the Swedish fund AP7 was recently quoted as saying, "The primary driver behind ESG isn't simply yield. It's values, both on behalf of the people in the industry and the societies around it" (Riley 2012). Beneficiaries don’t even rate a mention. Case closed.

3. Suppose an investor has a 20-year horizon; that the initial and sustainable annual $\beta$ is $8 \%$; and that she can extract an annual $\alpha$ of $2 \%$ for $T$ years, but at the cost of reducing the sustainable $\beta$ to $6 \%$. The 20-year annualized $\alpha$-extracting return exceeds the pure $\beta$ return only if $T>10$. With a more realistic $T=3$, the pure $\beta$ return is $20 \%$ greater, so she should care. But she should also account for the expected return from new opportunities she might capture precisely because $\beta$ was lowered by her activities.
4. The Court in Cowan v. Scargill, [1985] Ch 270, found against a union trustee of a miners' fund who resisted investing in alternative sources of energy on the grounds that it would be against members' interests. The Court ruled that he had acted in their interests as members of the union, not as members of the fund. The trustee had also resisted overseas investing on the grounds that it would so weaken the British economy that members would be materially disadvantaged. Obiter dicta, the Court sympathized with an argument against investing if those investments would likely result in a substantial destruction of the entire economy. In the Teachers' case (Withers v. Teacher's Retirement System of City of New York, 595 F.2d 1210 [1979]), the Court allowed a public pension fund to be used to bail out New York City via an investment that fell well short of traditional standards of prudence.

\section{References}

Johnson, K.L., and F.J. de Graaf. 2009. "Modernizing Pension Fund Legal Standards for the 21st Century.” Network for Sustainable Financial Markets: Consultation Paper No. 2. http://www.oecd.org/dataoecd/28/62/42670725.pdf

Keynes, J. M. 1936. The General Theory of Employment, Interest and Money. London: Macmillan.

MacNaughton, J. 2004. “Advocacy Groups: Butt Out of the Canada Pension Plan.” Globe \& Mail, September 9.

Riley, S. 2012. "Ethics Not Returns Drive AP7's ESG Policy.” Top 1000 Funds, March 7.

http://www.top1000funds.com/news/2012/03/07/ethics-not-returns-drive-ap7s-esg-policy/ 


\title{
Three Reactions and Differing Views on "Misadventures of an Irresponsible Investor"
}

\author{
In order to encourage thoughtful and continuous discussion in this area we invited Jane Ambachtsheer, \\ Stephen Davis and Keith Johnson, three individuals in the area of responsible investing, to share their \\ thoughts on Jack Gray's article "Misadventures of an Irresponsible Investor".
}

Jane Ambachtsheer is Partner and Global Head of Responsible Investment with Mercer (Canada).

It was a pleasure to read Jack Gray's intelligent critique of responsible investment. I have deep sympathy with several the points he makes, and concur with some of the conclusions drawn about how fiduciary behavior could evolve in the future. ${ }^{1}$

\section{First Things First}

Before getting to that, I wish to respond to a couple of points that Jack makes. First, he argues that trustees spend too much of their limited time considering environmental, social, and governance (ESG) factors, relative to their potential to improve member returns. Second, he argues one reason they do this is that addressing ESG concerns is both a (relatively) straightforward and a "feel good" affair. I wish I could agree with Jack on these two points (it would make my life considerably easier), but they are not consistent with my experiences:

- Too much time is spent on ESG: Mercer's Responsible Investment consulting unit is the largest in the industry, yet, with 15 people, we represent $1.2 \%$ of Mercer Investments' headcount. Further, a significant portion of our time is spent on research, intellectual capital development, and working with jumbo funds. I would surmise that - on average - pension funds spend less than $0.5 \%$ of their consultant usage (hours or budget) on ESG-related topics. However, recent research suggests that climate change alone (i.e., just one of many ESG issues) accounts for 10\% of risk in a hypothetical pension plan (Mercer 2011). Therefore, I would argue that current time allocated significantly underweights potential value at risk (by a factor of 20).

- ESG is straightforward and a "feel good" exercise: Trying to wrestle boards and committees to develop a common understanding of ESG - let alone a sensible approach to it - is a significant challenge. The topic typically creates great division, and the majority of financial professionals have - like Jack - a lingering sense that a moral agenda secretly underpins the field. Certainly, pockets of this do exist. ${ }^{2}$ Yet a broader set of forces has lifted the field out of a feel-good affair and catapulted it into the heart of risk management. This reflects the convergence of thinking about the path of our economic future in light of developments across several fronts, including demographics, the environment, communications and consumption patterns, global governance, and broad systemic interdependence. ${ }^{3}$ These developments render historically non-financial / non-reported information increasingly relevant to the short- and long-term performance of individual investments (companies, infrastructure assets, buildings), portfolio management, and the sustainability of capital markets as a whole. Figuring out how to manage associated risks and pursue related opportunities is a complex task. I suspect Jack's remarks about the deficiencies of an approach that sees investors "only invest in the good companies" may refer to a narrow segment of funds. The central objective of the ESG movement is to broaden and sharpen the lens through which investors see the world, markets, and particular asset classes and investments what they do with this information will depend on many things (their current position, time horizon, asset class, risk budget, etc.). The reality today is that, broadly speaking, the financial industry doesn't "get" the need for ESG analysis. Thousands of MBAs and CFAs graduate every year with no formal training on how to acquire, assess, and value this type of information.

\section{This is complex!}

Jack's rant is an acknowledgment of the complexity of the issues in question: there are no simple answers, as illustrated by his frustration and, at times, contradictory thoughts. On the more complex issue of the roles, rights, and responsibilities of fiduciaries, I both agree and don't agree with elements of Jack's argument.

First, he states that "pension funds should not be making policy decisions for society." He then articulates his disappointment at the lack of leadership pension funds have shown in asserting "collective power on behalf of their beneficial owners." 
We live in a world where the promises of liberal democracy are unrealized at best, and there is an increasing absence of commercially independent politics. Three forces are broadly recognized by political scientists in shaping global governance frameworks: companies, governments, and non-governmental organizations. Investors are the missing stakeholder (Ambachtsheer 2011), and a potentially powerful one with - critically - a long-term outlook (at least, this applies to pension funds). In this sense, I believe they can and must advocate for sensible policy outcomes. And they will only be effective if they do so with a unified, or at least coordinated, voice. While this practice is becoming more common, the scales (of long-term public and market vs. short-term commercial) are still seriously out of balance. ${ }^{4}$ The trick will be to shift some of the misplaced focus on active management and security selection toward managing beta through capital market engagement.

\section{Where do we go from here?}

Jack concludes with a rallying cry to challenge the eternal desire for economic growth, which could also allow for a re-assessment of the Sole Purpose Test. Such a re-assessment is already underway, with a small but growing body of literature exploring the role of fiduciaries in policy engagement in the context of loyalty, prudence, intergenerational equity, and the precautionary principle (see, e.g., Hawley et al. 2011).

In thinking about how we might put these concepts into action on a broader scale, we come back to some of the stumbling blocks discussed at the beginning of Jack's article (such as the plethora of names used by the responsible investment industry and the negative reaction many of them elicit).

- Do we frame these concepts in a way that engages and motivates boards and senior executives at long-horizon asset owners?

- How can the necessary "policy engagement units" be properly staffed, and their success measured and rewarded, in major funds around the world?

- How do we achieve the necessary levels of collaboration, which are still held up by problems of confidentiality, competition, varying priorities, levels of competence, and free-rider issues?

The promising news is that Jack's energy, creativity, and passion are focused on these challenges. We need more like Jack sufficiently knowledgeable and thoughtful to serve as crap detectors, but able to think critically about practical steps forward. While the debates taking place around ESG are challenging and sometimes frustrating, they reflect a changing fiduciary compass. It's going to take a concerted effort to get it to continue to shift in the right direction.

\section{Endnotes}

1. I am grateful to Ed Waitzer and Ryan Pollice for their comments on this response.

2. Further, it seems a relatively common mistake for responsible investment professionals to overemphasize the relative importance of ESG, and effectively end up telling mainstream analysts or investors that they are stupid. In my experience this is not an effective approach.

3. In a recent presentation on global security at Mercer's Asia-Pacific Investment Forum (March 2012), General Sir Rupert Smith, author and one of Britain's most distinguished generals, argued that we are currently undergoing a "slow-burning revolution" shaped by these forces. Further, his number-one recommendation to ensure global stability was to protect the global commons. This means beginning to properly value things like carbon and water.

4. An example is the case of lobbying on the Volcker Rule. From July 2010 to October 2011, financial institutions met with federal agencies to discuss it some 351 times, while public-interest groups held just 19 meetings (Lowrey 2012).

\section{References}

Ambachtsheer, J. 2011. "International Codes and Conventions: Are Pension Funds Missing in Action?" Rotman International Journal of Pension Management 4 (2): 26-36. http://dx.doi.org/10.3138/rijpm.4.2.26

Hawley, J., K. Johnson, and E. Waitzer. 2011. "Reclaiming Fiduciary Duty Balance.” Rotman International Journal of Pension Management 4 (2): 4-16. http://dx.doi.org/10.3138/rijpm.4.2.4

Lowrey, A. 2012. "Facing Down the Bankers." New York Times, May 30.

http://www.nytimes.com/2012/05/31/business/kelleher-leads-a-nonprofit-better-markets-in-fight-for-stricter-banking-rules.html

Mercer. 2011. Climate Change Scenarios - Implications for Strategic Asset Allocation. http://www.mercer.com/climatechange 
Stephen Davis is nonresident senior fellow in governance studies at the Brookings Institution; senior fellow at the Harvard Law School Program on Corporate Governance; and former executive director of the Millstein Center for Corporate Governance and Performance at the Yale School of Management (United States).

Jack Gray concludes "Misadventures of an Irresponsible Investor" on a solid note, but careens alarmingly on the way there. Throughout the piece he wrestles with a foundational problem in capital markets: the citizen-investors who are the chief suppliers of capital to markets today represent virtually the same universe as citizen-taxpayers. Can it make sense that agents for each institutional investors, on the one hand, and governments, on the other - behave in diametrically opposite ways? Most concepts of fiduciary duty seem to require this. Investing agents are to focus solely on narrow financials, ignoring systemic or extra-financial risks such as those expressed in the term ESG (environmental, social, and governance), which almost certainly bear on the longterm interests of grassroots beneficiaries. Gray seems to recognize by the end that this division between fiduciary and citizen duty is ultimately arbitrary and irrational, for example with respect to denuding global forests. The division is in fact a legacy of a longdisappeared capital market in which collective investment vehicles were trivial players. Such funds have grown to dominate equity ownership, but fiduciary duties guiding their behavior remain stuck in the early twentieth century.

The moment has indeed come to revisit fiduciary duty, and thinkers around the world - led by the Rotman International Centre for Pension Management, the Network for Sustainable Financial Markets, Fairpensions, and others - have begun this process. Gray does not particularly delve into the policy implications of the contradictions he outlines. Instead, he gets distracted - and entertainingly steamed - by sideshow misconceptions. For instance, he suggests that a shareowner's focus on ESG analysis will lead it to overpay for top-ranked stocks. In fact, investing shops commonly embed ESG factors to capture value even (maybe especially) where companies fall short. Gray is irritated that Citigroup can call itself a center of "responsible finance." But, believe me, few institutions will take that claim seriously just because CEO Vikram Pandit says so. Gray lashes fanatical investors in the United States who see ESG as the sole issue, but these are straw men; such institutions don't exist in great numbers. In truth, the more common criticism of mainstream American investors is that not enough of them acknowledge ESG factors as risk factors. Where they do, ESG is simply woven into investment analysis. Gray gets stuck on the word "responsible," arguing that the term should imply identical investor approaches to issues such as nuclear power. But being a "responsible" investor is really about making conscious and informed decisions aligned with the interests of beneficiaries. Outcomes may very well vary, on nuclear power and other matters, among different funds with different constituencies.

Gray contends that the frictions between fiduciary and citizen duties have been most harmful when governments have sold state assets into the private sector; short-term ownership resulted, to the detriment of the public good. Well, if he thinks we privatized too much before, just wait for what's coming. Debt-strapped governments are planning to spin off record numbers of enterprises to the market - even Prince William's helicopter rescue unit is to be sold. The issue to be addressed may be less about privatization than about the behavior of investors who inherit such assets. This brings us back to fiduciary duty. A fund that caters to citizeninvestors could start by doing what the United Kingdom's National Employment Savings Trust (NEST) does: conducting comprehensive research on the "characteristics, circumstances and attitudes" of members, and then shaping policies accordingly. Findings have led NEST to plan a long-term ownership focus that embeds ESG risk factors. Gray seems to ask why a fund should bow to such desires. Perhaps the better question is: Why should it not? 
In "Misadventures of an Irresponsible Investor," Jack Gray expresses his frustration with the seemingly irreconcilable differences between the investment methodology used by mainstream financial investors and approaches advocated by investors who incorporate environmental, social, and governance (ESG) factors into their investment practices. He finds fault with both belief systems and ends up feeling "unsatisfied and self-irritated." Much of his angst is attributed to the "separation of fiduciary and citizens" duties" seemingly mandated by the legal constraints of the sole purpose test, which requires that fiduciaries manage assets solely in the interest of fund participants and for the exclusive purpose of providing promised benefits. ${ }^{1}$

\section{Déjà vu All Over Again}

Gray's rant sounds eerily familiar. Turn the clock back 25 years, and fiduciaries of the 1980s confronted similar irreconcilable differences that involved competing views of fiduciary duty. A February 1988 review of a new book, Modern Investment Management and the Prudent Man Rule (Longstreth 1986), offers the following description of the conundrum faced by fiduciaries of that time:

The prudent man rule creates a legal paradox: It forces fiduciaries into an inherent contradiction. A fiduciary cannot behave as a careful, wise, discreet, judicious and prudent man if he acts within the strictures of a prudent man rule that forces him to behave imprudently in the contemporary economic marketplace. (Nicholas 1988, 779)

Of course, we now know how that contradiction was resolved: views of prudent investing that were based on legal lists of inherently prudent and imprudent investments were discarded in favor of modern portfolio theory. As part of that evolution, guidance was added to the Restatement of Trusts, Third (1992, §227, Comment (f)) cautioning that "there are no universally accepted and enduring theories of financial markets or prescriptions for investment that can provide clear and specific guidance to trustees and courts" (emphasis added).

All signs point to a similar present-day evolution taking place in our understanding of fiduciary duty. As Jeremy Grantham $(2009,2)$ observed, "The incredibly inaccurate efficient market theory [caused] a lethally dangerous combination of asset bubbles, lax controls, pernicious incentives and wickedly complicated instruments that led to our current plight." Washington Post financial journalist Roger Lowenstein (2009) was more direct: "The upside of the current Great Recession is that it could drive a stake through the heart of the academic nostrum known as the efficient-market hypothesis." ${ }^{2}$

\section{Winds of Change Are Blowing}

Much has changed in the global economy and markets since modern portfolio theory and the efficient-market hypothesis became the predominant investment approach during the last half of the twentieth century. Since then, advances in information technology have fundamentally changed the investment industry, introducing levels of complexity, speed, and short-termism that were unfathomable only a few decades ago. The growth of assets managed by institutional investors has turned the latter into economic powerhouses, collectively asserting unparalleled influence on society through their investment and capital allocation decisions. New cadres of consultants, advisors, and investment intermediaries have sprung up, diluting governing fiduciaries' accountability to their beneficiaries. ${ }^{3}$ Most importantly, a series of highly destructive economic crises over the past decade has undermined faith in the only set of investment beliefs that an entire generation of financial industry professionals has known.

Gray recognizes these challenges to mainstream financial industry practices, but he struggles to find an acceptable alternative. $\mathrm{He}$ is troubled by "the ever-changing names and nature" of different ESG investment styles, even though he treats integration of ESG factors as a compelling replacement. The primary roadblock to adoption of an ESG approach, he argues, is the sole purpose test of fiduciary duty. 


\section{Fiduciary Duty Is a Flexible Concept}

After several decades of investment-industry domination by modern portfolio theory and efficient-market beliefs, investment professionals (and many lawyers) have mistakenly come to view prevailing applications of finance theory as synonymous with fiduciary duty. However, the Restatement of Trusts, Third (1992, §227, Introduction), clearly states, "Trust investment law should reflect and accommodate current knowledge and concepts. It should avoid repeating the mistake of freezing its rules against future learning and developments."

If current investment practices are no longer fit for purpose in the twenty-first century, fiduciaries are not stuck with them. In the words of Bevis Longstreth, the leading commentator on fiduciary duty during its last great evolution, "Investment products and techniques are essentially neutral; none should be classified prudent or imprudent per se. It is the way in which they are used, and how decisions as to their use are made, that should be examined to determine whether the prudence standard has been met" (Longstreth 1986, qtd. in Nicholas 1988, 784).

\section{The Sole Purpose Test Is Multiple Choice}

"Misadventures of an Irresponsible Investor" also falls prey to a popular misconception about fiduciary duty. Many industry professionals mistakenly believe that the duty of loyalty, which includes the sole purpose test, requires fiduciaries to maximize short-term returns without regard to the longer-term consequences and systemic risks generated by their behavior. Nothing could be further from the truth.

In fact, governing fiduciaries are legally required to take a balanced approach that impartially balances the different short- and long-term interests of fund participants (Hawley, Johnson, and Waitzer 2011, 8). The US Supreme Court has specifically held that the fiduciary duty of loyalty extends not to the plan itself but to the beneficiaries as individuals. ${ }^{4}$

Under the duty of loyalty, fiduciaries cannot turn a blind eye to material risks and opportunities that are relevant to delivery of sustainable pension benefits to the human beings who are fund beneficiaries, especially if the fiduciaries' own management practices amplify those risks. Risks to the interests of beneficiaries in a sustainable retirement must be recognized and, to the extent reasonably practicable, must be managed in a way that is consistent with the interests of both current and future retirees. ${ }^{5}$ From a fiduciary duty standpoint, it is irrelevant that a risk factor or investment opportunity might be viewed as inconsistent with someone's moral values or personal beliefs; the duty of loyalty question is whether or not something affects delivery of intergenerationally equitable pension security.

However, many issues presumed to be beyond the bounds of investment theory or market-relative benchmarks can have systemic effects or involve consequences for the sustainability of an impartial standard of retirement security across generations. Environmental degradation and concerns about public health and public safety are prime examples. For instance, while common resources might be regarded as free goods or seen as irrelevant externalities in the context of traditional investment analysis, investment practices that contribute to water scarcity, air pollution, economic instability, energy shortages, rising health care costs, or food-supply contamination problems are highly relevant and material to the future economic interests of human pension-fund members. Analysis of the knock-on effects of investment practices, which may be invisible when viewed through a market-relative lens, takes on greater importance when viewed from the perspectives of fund participants and beneficiaries.

This confusion between market theory and the fiduciary duty of loyalty also generates frustration in "Misadventures of an Irresponsible Investor" about the separation of fiduciary and citizens' duties. In the twenty-first century, however, institutional investor fiduciaries have accumulated sufficient collective assets to exert a major influence on economic stability, business development, and the future of society. By default, institutional investors now affect public-policy decisions through their decisions about capital allocation, investments, and risk management. Even decisions to not decide can influence society and public policy.

For example, investor decisions to ignore the short- and long-term risks or benefits to beneficiaries of investing in nuclear-power companies or in alternative-energy companies become, through their collective impact, a public-policy decision with societal implications. Whether intentionally or not, institutional investor fiduciaries wield incredible influence, even by protecting the status quo. The challenge for fiduciaries is whether their influence is being managed in the interests of participants and beneficiaries. ${ }^{6}$ 
Fiduciaries are not required by the sole purpose test to pretend that their investment, capital-allocation, and risk-management decisions have no broader impact. They are also not immunized from responsibility for the reasonably foreseeable effects of choosing not to make a decision. While finance theory might ignore systemic effects of investment activities or the long-term financial impact of ESG factors, the fiduciary duty of loyalty is not so limited. Actions (and inactions) of fiduciaries must be both for the purpose of providing future benefits and in the interests of the human beings who are pension-fund participants and beneficiaries, in an intergenerationally unbiased manner. Viewed through the duty of loyalty, citizens' and fiduciaries' duties are often opposite sides of the same coin.

\section{The Way Forward}

"Misadventures of an Irresponsible Investor" ends with a plea for reassessment of the sole purpose test in the context of shortcomings associated with the dominant investment paradigm. However, there is nothing that bars the door to doing so for investors who apply a balanced view of fiduciary duty - other than institutional investor inertia. Fiduciary obligations are not circumscribed by popular finance theory.

Experience from the 1980s and from prior evolutionary transitions in the understanding of fiduciary duty should provide comfort to investors who fear they are embarking on a misadventure. During that time period, trustees began to widely ignore old views of prudence in response to new developments (Nicholas 1998, 782). The tension and confusion Gray describes are likely a sign that the popular understanding of fiduciary duty is once again at odds with economic reality and getting ready for a new transition.

Indeed, recent research has demonstrated that experienced asset managers with specialized ESG expertise can outperform conventional managers. ${ }^{7}$ The potpourri of sustainable investment approaches described in "Misadventures of an Irresponsible Investor" appears to have been nothing more than the evolution over time of efforts to address the disconnect between prevailing finance theory and fundamental principles of fiduciary duty. What began as ethical investing has grown into an increasingly sophisticated and integrated ESG investment approach that is still evolving (see Fulton et al. 2012).

However, the momentum for change is growing. Perhaps the next plateau will be an integrated investment approach that combines financial, environmental, social, governance, and company engagement (FESGE) practices. One thing is certain: investment models better suited to a properly balanced application of fiduciary duties in the twenty-first century will evolve only if investors devote the effort and resources to develop them. An equitable and sustainable future for pension-fund benefits depends on it.

\section{Endnotes}

1. In the United States, the sole purpose test for private pension funds is set forth in $\S 404(a)(1)$ of the Employee Retirement Income Security Act (ERISA). It requires that fiduciaries discharge their duties "in the interest of the participants and beneficiaries and for the exclusive purpose of providing benefits to participants and their beneficiaries and defraying reasonable expenses of administering the plan" (emphasis added).

2. Lowenstein (2009) quotes Yale University economist Robert Shiller as calling the efficient-markets hypothesis "the most remarkable error in the history of economic theory." See also Rajan (2012) for a critique of modern portfolio theory and practices.

3. See Hawley et al. (2011) and Davis (2012) for discussions of market changes and their effects on the application of fiduciary duty.

4. Varity Corp. v. Howe, 516 U.S. 489, 514 (1996).
5. See Hawley et al. (2011) and the Restatement of Trusts, Third (1992, §78), for discussions of the duty of loyalty.

6. The importance of institutional investor governance is highlighted by the default role these investors play in economics and policy making.

7. Gil-Bazo, Ruiz-Verdu, and Santos (2010) found that SRI specialists outperformed conventional funds with similar characteristics during their 1997-2005 study period. Kurtz and diBartolomeo (2011) conclude that social investment portfolios performed on a par with unconstrained portfolios between 1992 and 2010, when adjusted for investment factors. See also Fulton, Kahn, and Sharples (2012), who tracked the evolution of the different styles of sustainable investing and examined their returns. Their study, which differentiated evolving ESG investment approaches from prior iterations focused on exclusionary screens, found that more advanced ESG investment strategies correlate with superior risk-adjusted returns over the medium and long term. 


\section{References}

Davis, S. 2012. “Mobilizing Ownership: An Agenda for Corporate Renewal.” Issues in Governance Studies No. 48, Brookings Institution.

Fulton, M., B. Kahn, and C. Sharples. 2012. Sustainable Investing: Establishing Long-Term Value and Performance. DB Climate Change Advisors. http://www.dbcca.com/dbcca/EN/investment-research/investment_research_2413.jsp

Gil-Bazo, J., P. Ruiz-Verdu, and A. Santos. 2010. "The Performance of Socially Responsible Mutual Funds: The Role of Fees and Management Companies." Journal of Business Ethics 94 (2): 243-63. http://dx.doi.org/10.1007/s10551-009-0260-4

Grantham, J. 2009. "Obama and the Teflon Men, and Other Short Stories, Part 1." GMO Quarterly Newsletter, January. http://www.scribd.com/doc/13740736/GMO-2009-1st-Quarter-Investor-Letter

Hawley, J., K. Johnson, and E. Waitzer. 2011. "Reclaiming Fiduciary Duty Balance.” Rotman International Journal of Pension Management 4 (2): 4-16. http://dx.doi.org/10.3138/rijpm.4.2.4

Kurtz, L., and D. diBartolomeo. 2011. “The Long-Term Performance of a Social Investment Universe.” Journal of Investing 20 (3): $95-102$. http://dx.doi.org/10.3905/joi.2011.20.3.095

Longstreth, B. 1986. Modern Investment Management and the Prudent Man Rule. New York: Oxford University Press.

Lowenstein, R. 2009. “Book Review: The Myth of the Rational Market.”Washington Post, June 7.

http://www.washingtonpost.com/wp-dyn/content/article/2009/06/05/AR2009060502053.html

Nicholas, L. 1988. “Review: Modern Investment Management and the Prudent Man Rule.” Business Lawyer 43: 779-86.

Rajan, A. 2012. "The Death of Common Sense: How Elegant Theories Contributed to the 2008 Market Collapse.” White Paper, The 300 Club. http://www.the300club.org/Portals/0/The_300_Club_Death_of_Common_Sense_300412.pdf

Restatement of Trusts, Third (1992). 


\section{About Rotman International Centre for Pension Management}

The mission of the Rotman International Centre for Pension Management (Rotman ICPM) is to be an internationally-recognized, high-impact catalyst for fostering effective pension design and management. Its four primary tools to achieve this goal are the funding of objective and transformative research, the organization of interactive, action-oriented discussion forums, the publication of a readable journal relevant to professionals in the pensions and related fields, and the delivery of the globe's leading governance education program for Board members of pension and other longhorizon investment institutions.

Publisher and Editor

Keith Ambachtsheer

Associate Publisher and Editor Ann Henhoeffer

\section{Copy Editor}

Sylvia Hunter

\section{Design}

watermarkdesign.ca

\section{icPM \\ International Centre for \\ Pension Management}

151 Bloor Street West, Suite 702 Toronto, Ontario Canada M5S 1S4

Tel: 416.925 .4153

Fax: 416.925 .7377

icpm@rotman.utoronto.ca www.rotman.utoronto.ca/icpm

Rotman School of Management UNIVERSITY OF TORONTO

\footnotetext{
a new way to think I pension management
}

\section{Editorial Advisory Board}

Australia

Jack Gray - Sydney University of Technology

Gordon Hagart - Australia Future Fund

Wilson Sy - University of Western Sydney

\section{Canada}

James Davis - Ontario Teachers'

Pension Plan

Malcolm Hamilton - Mercer (Canada)

Lukasz Pomorski - Rotman School of

Management

Patrick Savaria - Caisse de dépôt et placement du Québec

\section{Denmark}

Ole Beier Sørensen - Danish Labour

Market Supplementary Pension (ATP)

Japan

Sadayuki Horie - Nomura Research Institute

\section{Netherlands}

Rob Bauer - Maastricht University

Dirk Broeders - De Nederlandsche Bank

Jean Frijns - Corporate Director

Theo Kocken - Cardano

Stefan Lundbergh - Algemene Pensioen

Groep
New Zealand

Tim Mitchell - New Zealand

Superannuation Fund

\section{Sweden}

Urban Karlström - Första AP-fonden (AP1)

\section{United Kingdom}

Gordon L. Clark - Oxford University

Roger Urwin - Towers Watson and MCSI Barra

\section{United States}

Don Ezra - Russell Investments Brett Hammond - MSCI Barra Stephen Lerch - Washington State Investment Board

Unsolicited articles can be submitted via PRESTO! for consideration by the Editorial Advisory Board. Please visit http://rotmanijpm.presto. utpjournals.com/jmanager/users/login.
ISSN 1916-9833 (Print) - C $\$ 50.00$

ISSN 1916-9841 (Online) - no charge

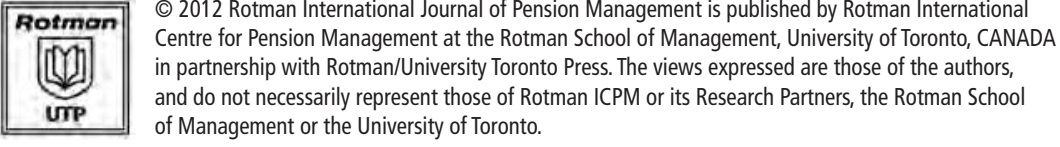

Rotman International Journal of Pension Management is distributed at no charge as an electronic journal and can be accessed by visiting www.rotman.utoronto.ca/icpm. Print copies can be purchased at a cost of $C \$ 50.00$ per issue (includes tax and shipping). To order print copies please visit www.rotman.utoronto.ca/icpm.

\section{()) $\Theta \Theta$}

This work is licensed under the Creative Commons Attribution-Noncommercial-No Derivative Works 2.5 Canada License Under Creative Commons, authors retain ownership of the copyright for their article, but authors allow anyone to download, reuse, reprint, distribute, and / or copy articles from the journal, as long as the original author(s) and source are cited. No permission is required from the Author(s) or the Publisher. To view a copy of this license please visit www.rotman.utoronto.ca/icpm. 